\title{
Near-Term Pathways for Achieving Forest and Agricultural Greenhouse Gas Mitigation in the U.S.
}

\author{
Christopher S. Galik ${ }^{1, *}$, Brian C. Murray ${ }^{2}$ and Meredith C. Parish ${ }^{1}$ \\ 1 Department of Public Administration, North Carolina State University, Raleigh, NC 27695, USA \\ 2 Energy Initiative and Nicholas Institute for Environmental Policy Solutions, Duke University, \\ Durham, NC 27708, USA; brian.murray@duke.edu \\ * Correspondence: csgalik@ncsu.edu; Tel.: +1-919-513-6011
}

Academic Editor: Bruce McCarl

Received: 13 July 2017; Accepted: 25 August 2017; Published: 1 September 2017

\begin{abstract}
U.S. forests and agriculture present unique opportunities to mitigate greenhouse gas (GHG) emissions. U.S. forests currently remove a large amount of carbon dioxide from the atmosphere each year and store it as a terrestrial carbon sink, a trend that is projected to continue, although at a decreasing rate over time. Agriculture is and will continue to be a net source of GHGs. To encourage additional mitigation, analyses suggest addressing forest loss, forest aging, wildfire, and encouraging greater forest growth. In agriculture, analyses suggest addressing animal operation methane emissions and nitrous oxide from fertilizer use. Absent new targeted policies to encourage mitigation practices such as these, existing programs may need to be better leveraged for GHG mitigation, even if that is not their explicit objective. Leveraging existing programs requires coordinated outreach efforts to ensure that practices are not cross-purposed. Development of standards and verification practices is also necessary to ensure desirable outcomes. Finally, greater mitigation may be possible by maximizing the effectiveness of voluntary efforts from private and non-governmental organizations, and not necessarily the implementation of new policies. This conclusion represents a departure from traditional commentary on the subject, but arguably represents a more realistic path forward to achieving climate mitigation objectives in the near-term.
\end{abstract}

Keywords: greenhouse gas mitigation; agriculture; forestry; climate policy; United States

For decades, research has sought to estimate both the consequences of global climate change on agriculture and forestry, as well the potential greenhouse gas (GHG) mitigation available from the two sectors [1,2]. More recent research has likewise sought to describe the policy and market means by which to achieve these contributions [3-6]. In practice, however, policies and incentives have yet to emerge to support forest and agricultural GHG mitigation efforts on a broad scale. Questions thus remain as to how agricultural and forest mitigation can be achieved in the near-term, defined here as the next 10-15 years, absent policies specifically targeted to addressing climate change.

The assessment below begins with a review of estimates of GHG mitigation potential from U.S. farms and forests. We discuss mitigation potential as identified in the literature and by public entities, providing estimates of both technical and economic mitigation potential where available. We then review the policy or market instruments capable of facilitating mitigation in the agriculture and forest sectors. Next, we briefly discuss the likelihood of new policy or market development in the near future, concluding with a brief discussion on the most likely path or paths for achieving GHG mitigation in U.S. forests and farms in the coming decade. 


\section{Estimates of Agricultural and Forestry GHG Trends and Mitigation Potential}

Policymakers and researchers typically group the agriculture and forest sectors together because land is the primary factor of production. In the United States, where a substantial majority of agricultural land and more than half of forestland is in private holdings, land can be and has been liberally substituted between these two uses [7]. An analysis of the GHG mitigation potential in these lands necessarily begins with an assessment of baseline trends and forecasts. Several such analyses have been conducted for U.S. forest and agricultural land in recent years. Notable among these are assessments conducted by the U.S. Environmental Protection Agency, the U.S. Geological Survey, and the U.S. Forest Service in fulfillment of domestic or international policy obligations. Differences in study scope, methodology, and primary assumptions make it difficult to directly compare the results between studies, but the studies nonetheless contribute to a general understanding of the direction and magnitude of carbon sequestration and GHG emissions in the coming decades.

\subsection{Baseline Trends and Forecasts}

According to the 2017 Inventory of U.S. Greenhouse Gas Emissions and Sinks, the agriculture sector released $522.3 \mathrm{TgCO}_{2} \mathrm{e} / \mathrm{yr}$ into the atmosphere in 2015, an increase of 5.4 percent since 1990 [8]. Key contributors to sector emissions included nitrous oxide emissions from agricultural soil management $\left(251.3 \mathrm{TgCO}_{2} \mathrm{e} / \mathrm{yr}\right)$, methane emissions from enteric fermentation $\left(166.5 \mathrm{TgCO}_{2} \mathrm{e} / \mathrm{yr}\right)$, and both methane and nitrous oxide emissions from manure management $\left(84 \mathrm{TgCO}_{2} \mathrm{e} / \mathrm{yr}\right)$. Smaller contributions came from rice cultivation, urea fertilization, liming, and field burning of agricultural residues $(11.2,5.0,3.8$, and $0.4 \mathrm{TgCO}<\mathrm{sub}>2</$ sub $>\mathrm{e} / \mathrm{yr}$, respectively). The land use, land-use change, and forestry (LULUCF) sector meanwhile sequestered $778.7 \mathrm{Tg}$ of carbon dioxide in 2015. Net additions to forest biomass outweighed conversions of forestland to agricultural land and urban land. LULUCF sector also emitted $9.7 \mathrm{TgCO}_{2} \mathrm{e} / \mathrm{yr}$ of methane and nitrous oxide, or 0.3 percent of the U.S.'s total GHG emissions in that year. Annual LULUCF carbon sequestration has decreased by 6.2 percent since 1990, however [8] (Table 1).

Table 1. Historical U.S. emissions and sequestration (in parentheses) from forest and agricultural sectors. All units expressed in units of $\mathrm{TgCO}_{2} \mathrm{e} / \mathrm{yr}$. Source [8].

\begin{tabular}{lccccccc}
\hline & $\mathbf{1 9 9 0}$ & $\mathbf{2 0 0 5}$ & $\mathbf{2 0 1 1}$ & $\mathbf{2 0 1 2}$ & $\mathbf{2 0 1 3}$ & $\mathbf{2 0 1 4}$ & $\mathbf{2 0 1 5}$ \\
\hline Ag. Mgmt. Non-CO $\mathrm{CO}_{2}$ Emissions & 488.3 & 518.5 & 533.9 & 515.6 & 508.5 & 506.4 & 513.4 \\
$\quad$ Enteric Fermentation & 164.2 & 168.9 & 168.9 & 166.7 & 165.5 & 164.2 & 166.5 \\
$\quad$ Manure Mgmt. & 51.2 & 72.8 & 80.4 & 83.1 & 80.8 & 80.4 & 84.0 \\
$\quad$ Ag. Residue Burning & 0.3 & 0.3 & 0.4 & 0.4 & 0.4 & 0.4 & 0.4 \\
$\quad$ Rice Cultivation & 16.0 & 16.7 & 14.1 & 11.3 & 11.3 & 11.4 & 11.2 \\
$\quad$ Ag. Soil Mgmt. & 256.6 & 259.8 & 270.1 & 254.1 & 250.5 & 250.0 & 251.3 \\
\hline Forest Staying Forest & $(697.7)$ & $(664.6)$ & $(670.0)$ & $(666.9)$ & $(670.8)$ & $(669.3)$ & $(666.2)$ \\
Land Converted to Forest & $(92.0)$ & $(81.4)$ & $(75.8)$ & $(75.2)$ & $(75.2)$ & $(75.2)$ & $(75.2)$ \\
Crops Staying Crops & $(40.9)$ & $(26.5)$ & $(19.1)$ & $(21.4)$ & $(19.6)$ & $(18.7)$ & $(18.0)$ \\
Land Converted to Crops & 43.3 & 25.9 & 23.2 & 22.7 & 22.7 & 22.7 & 22.7 \\
Grassland Staying Grassland & $(4.2)$ & 5.5 & $(12.5)$ & $(20.8)$ & $(20.5)$ & $(20.4)$ & $(20.9)$ \\
Land Converted to Grassland & 17.9 & 19.2 & 20.7 & 20.4 & 20.5 & 20.5 & 20.5 \\
Wetlands Staying Wetlands & $(7.6)$ & $(8.9)$ & $(7.6)$ & $(7.7)$ & $(7.8)$ & $(7.8)$ & $(7.8)$ \\
Settlements Staying Settlements & $(86.2)$ & $(91.4)$ & $(98.7)$ & $(99.2)$ & $(99.8)$ & $(101.2)$ & $(102.1)$ \\
Land Converted to Settlements & 37.2 & 68.4 & 70.7 & 68.3 & 68.3 & 68.3 & 68.3 \\
\hline
\end{tabular}

Another relevant analysis is the U.S. Forest Service's Update to the 2010 Resources Planning Act (RPA) Assessment [9]. Despite seeing increased carbon sequestration in forests over the last two decades, the RPA projects a decline in sequestration over the coming decades. The RPA's Reference scenario estimates that net carbon sequestration in the U.S. will decrease from approximately $480 \mathrm{TgCO}_{2} \mathrm{e} / \mathrm{yr}$ to $360 \mathrm{TgCO}_{2} \mathrm{e} / \mathrm{yr}$ from 2015 to 2060, a decline attributable to continued forest aging and forest disturbance. Regional differences in carbon sequestration are also projected to continue. In the Rocky Mountain 
Region, where forest aging and disturbance are strong influencing factors, carbon sequestration is expected to decrease from a $36 \mathrm{TgCO}_{2} \mathrm{e} / \mathrm{yr}$ sink to an $11 \mathrm{TgCO}_{2} \mathrm{e} / \mathrm{yr}$ source. The RPA concludes that land use is the dominant factor influencing carbon sequestration, while also highlighting the role of harvested wood products (HWP) as an important carbon sink over time [9].

A trio of reports from the U.S. Geological Survey have attempted to ascertain carbon sequestration in a broader array of U.S. ecosystems and managed lands over the next several decades. In the eastern U.S., the analysis projects an average carbon sequestration rate of approximately $825 \mathrm{TgCO}_{2} \mathrm{e} / \mathrm{yr}$ between 2006 and 2050, compared to $1024 \mathrm{TgCO}_{2} \mathrm{e} / \mathrm{yr}$ between 2001 and 2006 [10]. Though carbon sequestration was projected to increase in agricultural land and wetlands, the region-wide decline in carbon sequestration rate is largely attributable to forest aging and an associated decline in the rate of forest carbon storage [10]. Similar to the eastern region, carbon stored in western systems is likewise expected to increase between 2006 and 2050, but at a decreasing rate [11]. Meanwhile, carbon equestration in the Great Plains from 2006 to 2050 is expected to range between 223 and $542 \mathrm{TgCO}_{2} \mathrm{e} / \mathrm{yr}$, as compared to a range of 73 and $363 \mathrm{TgCO}_{2} \mathrm{e} / \mathrm{yr}$ between 2001 and 2006 [12]. Across all three regions, USGS finds that land-use change, declining forest sequestration capacity, and wildfire are important components in carbon sequestration trajectories in the coming half-century [10-12]. An array of practices are recommended to specifically address the expected decline in sequestration rate, such as conserving natural land cover (i.e., forests and grasslands) and maintaining soil sequestration capacity [12].

\subsection{GHG Mitigation Potential from Deliberate Actions}

The baseline sets the stage for what is likely to happen under business-as-usual (BAU) conditions, allowing estimates to be made of the potential GHG mitigation achievable through actions that intentionally depart from BAU for the purpose of lowering emissions or increasing carbon sequestration. The choice of baseline is an important decision, as it determines the magnitude of reported GHG emissions or reductions. Under the United Nations Framework Convention on Climate Change (UNFCCC), mitigation achievable through policies that are currently in place is included in a "with measures" projection [13]. Also reportable is mitigation achievable under other planned (but not currently implemented) provisions, or a "with additional measures" projection. A third "without measures" projection, showing GHG trends absent planned and/or implemented policies, may be used as a reference or baseline [13].

In practice, U.S. reporting has included the influence of existing policies in its baseline, termed the "current measures" projection in the latest Biennial report [14]. The 2016 Biennial Report outlined the U.S. path to reducing emissions pursuant to goals set by the Obama Administration, taking a multidimensional approach in addressing major contributors to GHG emissions across sectors identified by the Intergovernmental Panel on Climate Change (IPCC) (energy; transport; industrial processes; agriculture; Land-use, Land-use Change, and Forestry (LULUCF); and waste). The report noted that U.S. LULUCF has high GHG mitigation potential, but great uncertainties remain in projections. In 2013, for instance, LULUCF activities sequestered $900 \mathrm{Tg} \mathrm{CO}_{2} \mathrm{e}$, whereas year 2025 LULUCF GHG sequestration projections ranged from 908 to $1201 \mathrm{Tg} \mathrm{CO}_{2} \mathrm{e}$ [14].

Multiple reports have also documented the GHG mitigation potential from U.S. farms and forests under alternative policy or market conditions. One category of analysis consists of those which assume that mitigation is achieved through a price on carbon. These studies are informative in that they provide insight into the quantity of mitigation that may be delivered, as well as the cost of that mitigation and the relative contributions of different activities at similar carbon pricing levels. For example, Murray et al. (2005) assess the mitigation available under multiple carbon prices, by activity, over time, and across different regions of the country [15]. Though well-over a decade old at this point, the analysis is informative in that it demonstrates the large contributions made by forest management, afforestation, and reforestation activities at higher carbon prices, but also the availability of mitigation from agricultural management practices at lower carbon prices. It also 
points to an uneven distribution of GHG mitigation potential, with the southeastern and southcentral parts of the country, along with the Midwestern Corn Belt region, possessing the greatest potential; lesser mitigation is estimated to come from southwestern, mountain, and pacific regions. Nationwide, annual GHG mitigation in agricultural and forestry could average approximately $655 \mathrm{TgCO}_{2} \mathrm{e} / \mathrm{yr}^{\mathrm{by}}$ 2025 assuming a carbon price of $\$ 15 \mathrm{t} / \mathrm{CO}_{2} \mathrm{e}$ [15]. Changing the starting price or the trajectory of price change over time delivers a different portfolio of activities and different levels of reductions, but these results are nonetheless indicative of the magnitude of mitigation available.

The general findings by Murray et al. are replicated in other analyses of U.S. mitigation potential under a carbon price, particularly the large mitigation potential in U.S. forest lands from afforestation, reforestation, and forest management practices (e.g., improved forest management and rotation extension) [16,17]. Also consistent is the finding of disparity in the dominant mitigation practices and magnitude of potential GHG mitigation from region to region. Employing a different methodological approach, Lubowski et al. [18] arrive at similar conclusions regarding the large potential contributions from the forest sector, specifically stemming from forest expansion into rangeland, pasture, and cropland, but estimate higher marginal costs than studies using either bottom-up engineering approaches or economic optimization models.

Yet other assessments examine the aggregate GHG mitigation that arises from a change in practices, a change in commodity markets, or change in regulations. For example, the 2016 U.S. Mid Century Strategy (MCS) suggests that the agricultural and forestry sectors, combined with carbon dioxide removal technology, could sequester 30\% to 50\% of U.S. economy-wide greenhouse gas emissions [19]. The MCS outlines a portfolio approach of practices to sequester carbon through forestry such as afforestation and reforestation, avoided forest land conversion, improved management practices, improving forestry resilience, and the use of wood as an energy source [19]. Reducing deforestation from urban development, for instance, could avoid the loss of approximately $40 \mathrm{TgCO}_{2} \mathrm{e} / \mathrm{yr}$ by 2050 . If well implemented, sustainable soil sequestration practices such as agroforestry and cropland soil sequestration (e.g., no-till and other conservation tillage practices) could result in over $270 \mathrm{TgCO} 2 \mathrm{e} / \mathrm{yr}$ stored annually by 2050 [19].

Outlining the use of a particular set of actions to help achieve U.S. emission reduction obligations, the 2016 USDA Building Blocks report reviews agency programs with the potential to help farmers, ranchers, and forestland owners substantially mitigate GHG emissions. In total, the ten identified Building Blocks are projected to reduce emissions and/or increase carbon sinks by 121.7-135.7 $\mathrm{TgCO}_{2} \mathrm{e} / \mathrm{yr}$ by 2025 [20]. Of the ten Building Blocks, Energy Generation and Efficiency is expected to have the largest mitigating impact in the agricultural and forestry sectors, reducing emissions by $60.2 \mathrm{TgCO}_{2} \mathrm{e} / \mathrm{yr}$ by 2025 by increasing on-site renewable energy generation, building efficiency, and efficiency of stationary farm equipment. Livestock Partnerships has the second largest projected mitigating impact, reducing emissions by $21.2 \mathrm{TgCO}_{2} \mathrm{e} / \mathrm{yr}$ by 2025 through anaerobic digester installation, lagoon and waste pond coverage, and methane capture. Additional mitigation is achieved by 2025 through increased promotion of wood products $\left(19.5 \mathrm{TgCO}_{2} \mathrm{e} / \mathrm{yr}\right)$, reduction of nitrous oxide emissions $\left(7.0 \mathrm{TgCO}_{2} \mathrm{e} / \mathrm{yr}\right)$, increased soil health and conservation practices $(4.0-18.0 \mathrm{TgCO} 2 \mathrm{e} / \mathrm{yr})$, the protection and improved management of 1 million acres of additional private forest lands under the Forest Legacy and Community Forest Programs $\left(4.8 \mathrm{TgCO}_{2} \mathrm{e} / \mathrm{yr}\right)$, improved grazing management $\left(1.6 \mathrm{TgCO}_{2} \mathrm{e} / \mathrm{yr}\right)$, and conservation of sensitive agricultural lands, primarily by increasing enrollment in the Conservation Reserve Program (CRP) (0.8 $\left.\mathrm{TgCO}_{2} \mathrm{e} / \mathrm{yr}\right)$.

Another way that the agriculture and forest sectors can contribute to greenhouse gas mitigation is through the production of biofuel feedstocks that substitute for fossil fuel energy. The ability of biofuels to achieve GHG reductions is governed by a number of complexities associated with the feedstock used, the time rate over which feedstock growth and fuel emissions occur, changes in the intensity of feedstock management, and the effects of indirect land-use change induced by biofuel production [21-23]. Against the backdrop of these conceptual analyses, the 2016 Billion Ton Report (BT16) provides wide-ranging discussion of feedstock availability in the U.S. at various price points, 
noting that logistics will play an important role in the overall GHG score of assessed feedstocks, and suggesting that efforts to increase the efficiency of feedstock production could increase GHG reductions attributable to particular pathways. Improving yield also has the potential to increase the GHG performance of specific pathways. Even in the absence of improvement in these two areas, BT16 model analysis suggests net GHG reductions of approximately $4-9 \%$ relative to conventional, fossil-based fuels and products [24]. Elsewhere, the U.S. Biogas Roadmap details a variety of supporting initiatives to increase the market penetration of renewable natural gas, such as permitting biogas-derived pathways under the Renewable Fuel Standard (RFS), leveraging existing grant funding, improving communications, supporting increased data availability, and conducting original analysis. If the targeted deployment of 11,000 new biogas systems were to be achieved, net GHG reductions could reach 4-54 $\mathrm{TgCO}_{2} \mathrm{e} / \mathrm{yr}$ by 2030 [25].

Concerted effort has been devoted to assessing the mitigation potential of individual practices. A 2013 report by ICF International documents dozens of activities across the agricultural sector, arraying them by region and size of operation [26]. A follow-up report to that 2013 study extended the analysis to produce national marginal abatement cost curves, providing insight into the potential magnitude of GHG mitigation available through agricultural practices at multiple price points (Figure 1) [27]. In the absence of comprehensive climate policy in the near-term, the interesting set of activities will be those that are achievable at a price less than the likely range of existing compliance and voluntary carbon markets in the near future. With current and near-term prices for the California market falling in the mid- to high-teens, $\$ 20 / \mathrm{tCO}_{2} \mathrm{e}$ is a reasonable high-end estimate [28]; activities that are viable only at higher prices are unlikely to receive the necessary support to be widely implemented. Of course, each practice category detailed in Figure 1 is subject to considerable internal variability in cost and sequestration potential. Other analyses have sought to quantify this uncertainty, finding a wide variation in both observed sequestration capacity within a given practice and the available evidence between different practices [29]. Nonetheless, a subset of activities emerge as having both large relative average mitigation potential and large relative applicable area, particularly adoption of no-till or other conservation tillage practices, use of winter cover crops, and the management of species composition on grazing lands [29].

As stated at the outset, the reports reviewed above are not directly comparable, but a few key themes nonetheless emerge. One is the general trend of agriculture as a net emissions source and forestry as a net sink. A variety of practices contribute to the former, primary ones being methane emissions from animal operations and nitrous oxide emissions from fertilizer use. A variety of drivers likewise contribute to the forestry sink, including forest loss, forest aging, and wildfire on the negative side of the ledger and forest area expansion and forest regrowth on the positive side. Another general trend is the availability of fairly low-cost but low-magnitude GHG mitigation opportunities in agriculture, and higher-cost higher-magnitude opportunities in forestry. Together, these trends can help to set the context for the types of programs or policies best suited to facilitate mitigation in the agricultural and forestry sectors in the immediate future.

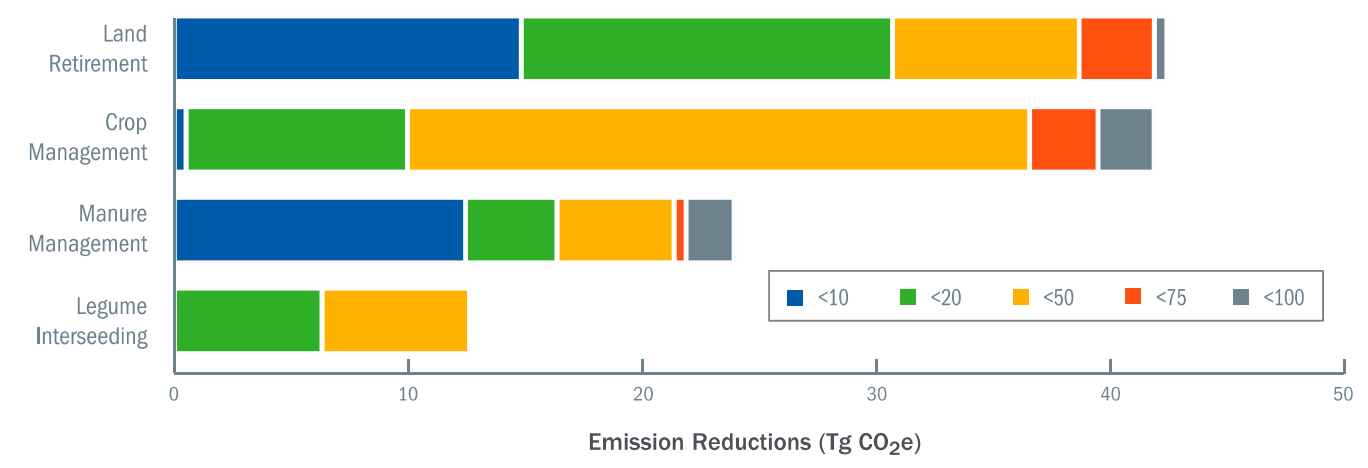

Figure 1. Potential annual mitigation by agricultural practice and price $\left(\$ / \mathrm{tCO}_{2} \mathrm{e}\right)$. Source: [27]. 


\section{Policy Options to Achieve GHG Mitigation in the Forest and Agricultural Sectors}

The previous section considers baseline levels of GHG emissions and carbon sequestration in forestry and agriculture as well as levels that could be achieved by enacting policies aimed at mitigating GHGs. Such policies could, in principle, fall into one of four categories.

\subsection{Direct Government Action}

Governments can act on regulatory authority they have over land use to require certain activities to mitigate GHGs on private lands. As a general matter, private land-use restrictions are more of a state and local matter than a federal one in the United States, though they may be in response to a federal statute (e.g., the Clean Water Act). While states, counties and municipalities do enact land-use ordinances, they are seldom if ever targeted at GHG mitigation. For instance, there may be state forest practices acts that limit or exclude timber harvesting in certain areas, but these are not typically aimed at forest carbon sequestration as a primary goal.

A number of resource agencies at the federal and state level are also responsible for managing publicly owned lands and must decide how to manage them. For instance about 250 million acres of forestland are managed by the federal government [7], primarily through the U.S. Forest Service and the Bureau of Land Management. The management plans governing these agency actions go through extensive planning and review processes and could well be developed to take forest carbon sequestration or other GHG mitigation benefits into consideration [30].

Governments at different levels can also mandate-or, in some cases, establish non-mandatory goals - that a certain amount of energy is produced by renewable sources. Currently, about 30 U.S. states have renewable portfolio standards that mandate minimum percentages of electric power from renewable sources, including biomass [31]. These standards create an economic incentive for the production and use of biomass as an energy feedstock.

\section{2. "Carbon" Price}

A carbon price has long been considered a possible option for mitigating GHGs from forestry and agriculture [15]. This type of policy mechanism creates a price per unit of GHG (usually per ton of $\mathrm{CO}_{2} \mathrm{e}$ ) that rewards reductions in $\mathrm{GHG}$ emissions. For agriculture and forestry, this could be reductions of $\mathrm{CO}_{2}$, methane (converted to $\mathrm{CO}_{2} \mathrm{e}$ for pricing purposes), or nitrous oxide and/or increases in $\mathrm{CO}_{2}$ removed from the atmosphere and sequestered in forest pools or soil.

The carbon price approach follows from consideration of various "cap-and-trade" proposals at the U.S. federal level starting midway through the first decade of the 21st century. The policy momentum for carbon pricing at the federal level started in earnest with the introduction of the bipartisan McCain-Lieberman Climate Stewardship Act (S 139) in the Senate in 2003. While the bill did not pass, it received more votes than anticipated and set the stage for successor bills in both chambers of Congress, culminating in the Waxman-Markey American Clean Energy and Security Act (HR 2454), which passed the House of Representatives in 2009, but failed to advance in the Senate. While Waxman-Markey covered about 85 percent of the country's emissions, forests and agricultural sources themselves were not subject to the cap. However, reductions and sequestration in those sectors were eligible to generate emissions offset credits, which could be sold at the carbon price to firms in the regulated sectors that did have compliance obligations.

There has been little momentum to establish a national carbon market since July of 2010, when the U.S. Senate announced it would not consider the companion bill to HR2454. California did enact a cap-and-trade program that was similar in scope, meaning it does have offsets for some forest and agricultural activity. So far, however, California forest and agriculture offsets have been limited in scale-far less than the mitigation potential estimates discussed in the previous section. Nine northeastern U.S. states instituted the Regional Greenhouse Gas Initiative in 2009, a cap-and-trade 
program for power plant $\mathrm{CO}_{2}$ emissions, with forest and agriculture offsets eligible, but program prices have been too low to induce any offsets to market.

While the California and RGGI programs create a carbon price through market-based regulatory action, there is also a carbon price through markets driven by voluntary demand for carbon offsets (e.g., the American Carbon Registry (ACR), Climate Action Reserve (CAR), and Verified Carbon Standard (VCS)). These programs cover a larger portfolio of agriculture and forest activities than do the California and RGGI regulatory programs. In addition to the agriculture categories in California and RGGI, the voluntary market creates offset demand for soil carbon sequestration from agricultural practices, nitrous oxide reductions from fertilizer management, grassland management, livestock management (including enteric fermentation), avoided conversion of grasslands, and wetlands restoration. These activities cover a majority of the full agricultural emission reduction potential referenced in the previous sections. Yet, these voluntary carbon market activities have not had a high rate of adoption, either in terms of the number of projects undertaken or the percentage of credits generated [32]. Low adoption rates may be due to a general lack of demand for voluntary offsets, the economic particulars of agricultural and forest mitigation activities, or both.

While there has been limited momentum for the U.S. to incorporate forestry or agriculture into regulatory compliance-driven carbon pricing systems, it is illustrative to look at countries that have explored this option. One country-New Zealand—has a regulatory system that includes these sectors in some fashion. Forestry is part of New Zealand's economy-wide emissions trading system [33]; land that was in forest before 1990 must submit New Zealand Units (NZUs) to cover emissions that occur from deforestation. If the land is harvested and replanted, there is no emissions compliance obligation. Land established as forest after 1989 can opt in to the Emission Trading Scheme (ETS) to earn "removal" credits for the amount of carbon removed from the atmosphere and stored as carbon stocks, which they can sell to other parties who have to meet emissions obligations. Though some exemptions exist, New Zealand forest owners generally do face a carbon price and thereby have incentives to keep carbon stored in forests. In contrast, New Zealand's agriculture sector, which accounts for 48 percent of New Zealand emissions [34], is not subject to compliance obligations to cover its emissions by submitting NZUs, though there is mandatory reporting of emissions from the sector [35].

Australia's Carbon Farming Initiative (CFI) incentivizes farmers to mitigate GHGs from agricultural and forest land practices by generating emission offset credits for those actions on a per tonne $\mathrm{CO}_{2}$ equivalent basis. Farmers can sell these credits through a government-funded Emissions Reduction Fund or to private party buyers in the voluntary offsets market [36]. The CFI at one time had been seen as a core component of Australia's economy-wide cap-and-trade emissions trading system, but that system was repealed in 2014.

Common themes emerge from the carbon pricing experiences in the U.S., New Zealand and Australia. One is that the sectors have remained largely out of emissions compliance requirements (with the limited exception of New Zealand forests) and have been primarily included in voluntary offset credit generation efforts, which limits the strength of incentives for mitigation. Accordingly, the uptake by farmers has been low. Substantial work has been aimed at developing market-based incentives for farmers and forest owners, however, as crediting protocols have been developed and outreach efforts have been expanded.

\subsection{Government-Financed Incentives}

Another way to induce private landowners to undertake mitigation activity voluntarily is for the government to pay them to do so. There is a long history of these types of programs in the U.S., for instance the Conservation Reserve Program (CRP) and the Wetlands Reserve Program (WRP), administered by the U.S. Department of Agriculture (USDA). These payments are not specifically targeted for carbon or GHGs, though they could be modified to be. Whether or not such a modification would occur, the actions that are paid for (e.g., tree-planting, wetlands restoration, fallowing, adoption of no-till agriculture) generally provide some measure of GHG mitigation; the 2016 
U.S. Biennial report, for example, estimates that the CRP and activities administered under the Natural Resources Conservation Service alone contribute approximately 50-60 $\mathrm{TgCO}_{2} \mathrm{e} / \mathrm{yr}$ of GHG mitigation [14].

The USDA also issues Conservation Innovation Grants (CIGs) to "stimulate development and encourage adoption of innovative conservation approaches and technologies." Some of these grants have been specifically targeted for GHG mitigation activity. Though relatively small in scale, the idea behind CIGs is to develop innovative programs that are further disseminated to ideally enhance broader adoption.

The government can likewise incentivize land-based GHG mitigation activity through tax incentives, although this is often an indirect incentive for farmers. For instance, the federal tax code has had various subsidies for fuel producers to produce biofuel blends, which creates a demand for biofuel feedstocks that incentivizes farmers to produce those feedstocks [37]. These credits are in various states of play, with some recently extended and others recently terminated but subject to industry efforts to reinitiate [38].

\subsection{Information Programs and Technical Assistance}

The USDA, in cooperation with land-grant universities throughout the United States, has provided technical assistance to farmers and forest owners for over 100 years through agricultural and forest extension programs established by the Smith-Lever Act of 1914. These extension programs, which aim to anchor their technical assistance in scientific evidence-based practice, cover the full range of agricultural and forest management activity. In the last decade, this has grown to include technical guidance on practices that mitigate GHGs (see, e.g., [39]). This technical assistance allows farmers to consider whether and how to engage in the agricultural offsets referenced in the carbon pricing discussion above, or perhaps the private voluntary actions as discussed below.

The EPA's AgSTAR program is specifically aimed at providing information and data on biogas recovery in the agricultural sector, primarily from animal manure management. The underlying notion is that biogas (essentially methane) can be generated by anaerobic digestion and captured rather than be emitted directly into the atmosphere. The captured biogas can also be used as a productive energy input if attached to an electricity generating device or conditioned and injected into a natural gas pipeline [40]. By encouraging the destruction of methane that would otherwise be emitted to the atmosphere, these programs can produce GHG benefits, especially if the captured methane is used as a substitute for fossil fuels. Possible revenue streams for farmers adopting these technologies include sales (or cost displacement) of electricity and natural gas, as well as sales of renewable energy credits to meet renewable portfolio standards and GHG emission offset credits as referenced above [41].

\section{Near-Term Opportunities and Incentive Streams}

Since taking office in January of 2017, the Trump Administration has indicated that the use of federal policy to reduce national GHG emissions will be a much lower priority than it was in the previous Administration [42]. There nonetheless remains interest across various stakeholders about what actions could be taken to motivate GHG mitigation in the near-term. We consider three general streams of policies here for agriculture and forestry. The first is the suite of existing policies and programs already in place at federal, state, and local levels. The second consists of new policies or programs that could be included in the upcoming federal Farm Bill reauthorization legislative process or developed under existing authorities at the USDA or other federal agencies. The third includes regulation, funding, or direct-action strategies implemented by non-federal actors, private finance, or non-governmental organizations. Each is further discussed below.

\subsection{Continued Use of Existing Policies and Programs}

There are a variety of policies and programs already being implemented by federal and state entities with the potential to encourage greater GHG mitigation in forestry and agriculture. The U.S. 
Biennial report referenced above notes several in its review of current policies and measures, including the RFS, conservation programs like the CRP, stewardship and management programs operated by the Natural Resource Conservation Service, biogas reduction operations under the AgSTAR program, and hazardous fuels reduction and forest restoration programs [14]. GHG mitigation estimates are not available for each and every activity listed, but could collectively yield well over $200 \mathrm{TgCO}_{2} \mathrm{e} / \mathrm{yr}$ in annual reductions by 2020 .

Recent analysis highlights the role that existing efforts have in driving GHG emissions and sequestration in the U.S. land sector. In a review of current policies with the potential to affect GHG mitigation in forests, agriculture, and other, non-working lands, McGlynn et al. consider the types of policy actions referenced in the previous section (e.g., regulations, government incentives, data and technical assistance, etc.) [4]. Across these categories of activities, the review identifies 70 authorizing or facilitative policies or programs in operation at the time of the report. Arraying the budgets for these practices (a rough proxy of programmatic reach or capacity) by the area of effect (a rough proxy of the GHG sink or flux they could influence) creates a visual indication of both gaps and opportunities present in current policy (Figure 2).

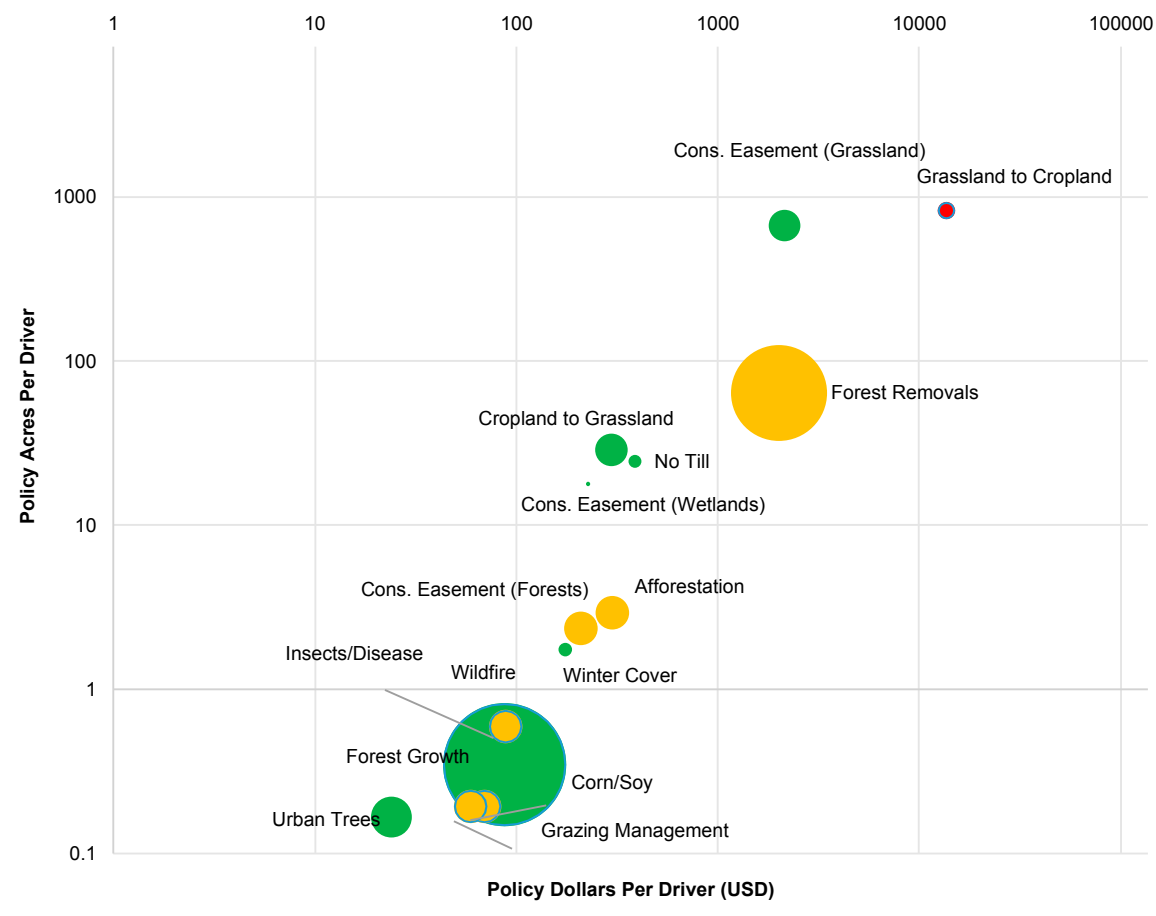

Figure 2. Policy scope and area reach of selected U.S. policies with the potential to influence GHG mitigation in forests and agriculture. Green circles represent net GHG reductions, yellow circles represent uncertain mitigation benefits, and red circles represent net increases in GHG emissions. Source: [4].

Apart from program summaries and analyses, efforts have been made in recent years to better coordinate existing programs and authorities to achieve greater GHG mitigation in practice, such as the aforementioned USDA Building Blocks initiative. Even in the absence of new authorities, efforts to better coordinate or communicate the existence of tax and other incentives can help to facilitate preservation or sustainable management activities [43,44]. If mitigation is to be achieved or facilitated through existing programs, many of which may not be specifically targeted to carbon storage or GHG emissions reduction, it is necessary to first identify relevant programs and then determine how they can be best leveraged to achieve climate benefits [4]. Such an exercise is well beyond the scope of this short review, but a few examples are nonetheless worthwhile to provide. For example, Clean Water Act incentives for increased nutrient management by Confined Animal Farming Operations (CAFOs) could 
have ancillary GHG benefits by addressing ammonia and other pollutants [26]. Habitat mitigation requirements as driven by the Endangered Species Act or wetland mitigation requirements motivated by the Clean Water Act and its implementing regulations could also serve as a vehicle to also emphasize GHG mitigation [4].

Opportunities also exist in state and local-level programs to encourage GHG mitigation in forest and agricultural sectors. To date, California and the northeastern states in the RGGI program plan to continue and even strengthen their cap-and-trade policies into the future and other states have pledged to pursue climate action following the decision of President Trump to withdraw the United States from the Paris Agreement [45]. These efforts are unlikely to fully compensate for a near-term absence of climate policy at the federal level, and the effect that expansion of state programs would have on incentives for land-based GHG mitigation is far from clear, but they do underscore that actions on climate change emerge from a dynamic involving many different levels of government and a diverse set of constituencies.

There likewise exists countless non-GHG policies enacted at the state and local level with the potential to influence mitigation efforts in the forest and agriculture sectors. "Smart growth" strategies implemented by state and local governments can help to reduce working land competition with urban development [19]. Habitat management and protection provisions meanwhile can help to encourage the maintenance of vegetation (and by extension, carbon) on those sites subject to development [46]. The GHG mitigation achieved through these and similar programs will be a function of the practices encouraged (e.g., fertilizer management, forest retention, soil carbon management), thus the wide array of program designs and conditions under which they are implemented makes estimation of net GHG reductions incredibly difficult.

\subsection{New Farm Bill or Agency Initiatives}

In their review of the literature of forest and agricultural mitigation potential, McGlynn et al. detail over two dozen new policies or practices that could be implemented to increase GHG mitigation [4]. Many of these programs and practices require new authorities, however, limiting their near-term potential. At the same time, negotiations around the primary vehicle for U.S. federal agricultural policy—the Farm Bill—have begun in earnest. The Farm Bill operates on approximately a five-year schedule, and provides both authorization and appropriations for a wide array of policies and programs with the potential to affect the way forests and farms are managed.

Though is unlikely that new policies or practices to specifically address GHG mitigation will find their way into the latest iteration of the Farm Bill, it is possible that new programs unrelated to GHG mitigation could still bring additional carbon storage or GHG emission reduction as a co-benefit. One example worth noting is the Soil Health and Income Protection Program (SHIPP) proposed by Sen. John Thune (R-SD) [47]. SHIPP is a short-term (3-5 years) conservation program for low-productivity acres that provides rental payment and crop insurance assistance. The program, requires a "low-cost perennial" to be planted on enrolled acres, with possible harvest after nesting or brooding season. Such a policy could generate GHG reductions, for example, should it be effective in stemming the reversion of currently-uncultivated lands into crop production [48,49].

More broadly, support for conservation programs remains high [50]. Though programs such as the CRP have seen decreased enrollment in times of high commodity prices, a recent run of low prices has led to a call to increase the cap on CRP acres [51]. Current discussions suggest an increase to 30 million acres, a 6 million acre increase over the current cap as set by the 2014 Farm Bill [51]. Depending on the conservation practices implemented, increases of this magnitude hold significant GHG mitigation potential. Recall that the USDA Building Blocks aim to increase GHG mitigation by $0.8 \mathrm{TgCO}_{2} \mathrm{e} / \mathrm{yr}$ by reforesting an additional 400,000 acres of CRP land [20]. Elsewhere, Wear and Coulston consider a hypothetical, CRP-like afforestation policy across approximately 20 million acres of land, nationwide, yielding an increase of $689 \mathrm{TgCO}_{2} \mathrm{e} / \mathrm{yr}$ between 2013 and 2025 [52]. 
Changes have also been suggested for the CRP and other easement-based programs to allow increased flexibility in management of enrolled lands. Sen. Thune proposed allowing enrolled lands "to be mitigated for land of equal or greater conservation and wildlife benefit" [51]. Important details are missing on how such a program would operate, but the general concept suggests the possibility of using federal conservation programs as a stepping-stone to increased environmental benefits, potentially including GHG mitigation. There remains an open question as to whether carbon can be included in the calculation to meet the threshold of "equal or greater ecological and economic values compared to the acreage that is mitigated" [51].

In addition to support for conservation programs, multiple stakeholders have identified farm safety net programs as an important concern going into the next Farm Bill, particularly those programs that guard against aforementioned long-term price declines. While there is increased interest in these programs, there is also a general sense that there will be less money to go around [53]. Past studies have assessed opportunities to restructure support programs to facilitate carbon storage and cost savings, showing the potential to increase carbon sequestration by more than $366 \mathrm{TgCO}_{2} \mathrm{e} / \mathrm{yr}$ at a cost savings of over \$6 Billion [54], but a policy shift of this magnitude is presently unlikely.

The concept of using crop insurance to encourage climate adaptation and mitigation behaviors has also emerged in recent years [19], though specific provisions encouraging this have yet to be seen in early Farm Bill discussions. The same is true for increased use of wood products, such as deployment of tall wood buildings $[19,20]$. In the case of both crop insurance reform and the creation of new markets for forest products, GHG mitigation can be yielded through increasing the incentive to invest in higher carbon land uses and reducing the incentive to convert to lower carbon ones $[22,55]$. The use of wood products to substitute for other building materials also has potential GHG benefits owing to the greater amount of emissions associated with the production of steel or cement alternatives [56].

It is equally possible that existing programs that currently achieve some measure of GHG mitigation could be modified or removed completely, reducing the amount of mitigation achieved by farms and forests. For example, Monke (2017) reports that there are several dozen Farm Bill programs that operate without a budget baseline, making them more vulnerable to reduced or eliminated budgets in future Farm Bill reauthorizations [57]. While most of these programs are largely irrelevant to agricultural and forest mitigation, multiple bioenergy programs are potentially vulnerable, including the Biomass Crop Assistance Program (BCAP) and the biorefinery assistance program. It is difficult to approximate the marginal contribution each of these programs contribute to current patterns of GHG emissions and carbon sequestration, though one analysis suggests that $\mathrm{BCAP}$ operating alongside the RFS reduces net GHG emissions by $300 \mathrm{TgCO}_{2} \mathrm{e} / \mathrm{yr}$ over the course of a decade relative to the RFS operating by itself [58].

\subsection{Private Sector and NGO Interventions}

With uncertainty about the scale and scope of government policy efforts to reduce GHGs, voluntary mitigation efforts in agriculture and forestry may be an important path for the next several years in the United States [59]. For example, Lewandrowski and Zook (2015) identify a host of other vehicles by which farmers could engage more in agricultural mitigation [60], including private sector supply chain initiatives and joint public-private partnerships focused on voluntary GHG mitigation. Facing pressure from investors and consumers alike, corporations have demonstrated an ability to address environmental concerns in the agricultural and forest sectors. The world's largest retailer Walmart has long been an impetus for these efforts and in early 2017 pledged to reduce one gigaton of GHG emissions from its supply chain, including products originating in the agriculture and forestry sectors [61]. Other prominent examples include Smithfield Foods, Cargill, Monsanto, and General Mills $[62,63]$. Taken both individually and as a whole, these private sector and NGO activities have the potential to expand land-based mitigation, but their scale will depend on sustained public and private sector budget commitments. In recognition of this potential gap in either capacity or motivation, 
recent years have seen an expansion of private conservation finance, a prominent example being NatureVest, a joint initiative between The Nature Conservancy and JP Morgan Chase \& Company [64].

\section{Conclusions, Challenges, and Opportunities}

So what can be said of near-term opportunities for GHG mitigation in U.S. agricultural and forest sectors? If we are to begin by addressing the greatest emission sources and sinks, then available data suggest that early efforts in the agricultural sector should focus on addressing methane emissions from animal operations and nitrous oxide emissions from fertilizer use. In forestry, the data suggest an emphasis on addressing forest loss, forest aging, and wildfire, while encouraging greater forest growth. Apart from the magnitude of mitigation potential, other considerations are likewise relevant, such as cost and the timing of mitigation (Table 2). There are trade-offs to consider, as well. For example, some activities are more expensive in absolute terms but result in greater mitigation (afforestation, for example), yielding a lower per-ton cost of mitigation. Some activities like afforestation may also take long periods of time to yield significant mitigation, whereas others may yield GHG emission reductions on much shorter timescales (e.g., fertilizer management). Finally, there is a need to carefully assess the broader implications of any strategy to increase GHG mitigation. An important example in this regard is any effort to address a decline in forest sequestration over time, as well as the difficulties associated with appropriately accounting for sequestration changes given the complexities of changing climate and associated disturbances. For example, replacing older, slower growing trees with younger ones may lead to an increase in emissions, as might any effort to reduce long-term emissions from catastrophic wildfire $[65,66]$.

Table 2. Relative magnitude, cost, and timing of select practices to increase GHG mitigation in the U.S. forest and agricultural sectors. The number of symbols in each column provides a relative ranking of practice performance, ranging from low to high (for magnitude and cost) and short to long (for timing). "Varies" indicates substantial range for a practice depending on the details of a particular application.

\begin{tabular}{|c|c|c|c|}
\hline Practice & Magnitude & Cost & Timing \\
\hline \multicolumn{4}{|l|}{ Agriculture } \\
\hline Land Retirement & ++ & $\$ \$$ & (ㄴ) (ㄷ) \\
\hline Manure Mgmt. & ++ & $\$ \$$ & (1) \\
\hline Fertilizer Mgmt. & + & $\$$ & (4) \\
\hline Conservation Tillage & ++ & $\$$ & (4) \\
\hline Rangeland Mgmt. & ++ & $\$$ & (4) \\
\hline Cropping Practice & + & $\$ \$$ & (t) \\
\hline \multicolumn{4}{|l|}{ Forestry } \\
\hline Forest Management & +++ & $\$ \$$ & (1) (1) \\
\hline Afforestation & +++ & $\$ \$ \$$ & (1) () (1) \\
\hline Avoided Conversion & + & $\$ \$ \$$ & (1) \\
\hline Expanded Markets & Varies & Varies & Varies \\
\hline
\end{tabular}

As the review above indicates, there are already a large number of programs with the potential to achieve varying amounts of GHG mitigation across forest and agricultural sector activities. Greater use of existing programs is one alternative to the creation of new ones, implying that outreach and engagement efforts are warranted to ensure that available resources are being leveraged as well as possible. The USDA Building Blocks represent but one approach to use existing programs to generate additional GHG mitigation, but countless other opportunities exist across local, state, and federal governments and in the private sector.

One concern with consciously leveraging a variety of individual programs to achieve GHG mitigation is coordination, or ensuring that the programs are not cross-purposed or that they do not result in negative co-effects (e.g., conversion of native habitat in favor of high-production 
monocultures). A wide array of programs not specifically designed to achieve GHG mitigation may be increasingly relied upon to achieve just that. As a result, greater emphasis on the development of standards and installation of appropriate verification practices is necessary to ward off unintended negative consequences. For example, research has documented the potential of indirect market effects to negatively affect GHG mitigation efforts by inducing the increased use, production, or consumption elsewhere, be it in the case of biofuel production [23], timber set-asides [67], or expanded use of wood products [56]. Expanded use of existing programs likewise requires careful attention to setting an appropriate baseline so as to judge additional contributions. Failing to distinguish between what would have been done anyway under existing authorities and what is the product of new outreach initiatives, expanded program budgets, or expanded program offerings threatens to inflate reported gains regardless of actual mitigation achieved.

Despite a robust and established literature on GHG mitigation opportunities in the forest and agricultural sectors, actions to realize those opportunities have been limited. Though one may ask whether agricultural and forest mitigation is better suited to a carbon price approach, as discussed above, or as part of complementary policies and private sector initiatives (e.g., [60]), the argument is somewhat moot at the present point in U.S. history. Practitioners must pursue the options available to them. Recent statements and committed practices by private and non-federal government stakeholders suggests that there is a willingness to pursue GHG mitigation, so the most important question is how to tap that willingness with the policies and mechanisms in place, rather than how to design the optimal policy framework.

Acknowledgments: The authors gratefully acknowledge research assistance provided by Emery Kiefer and Nicholas Riggs. The views, findings, conclusions, and recommendations expressed in this article are those of the authors. Partial funding was provided under USDA Cooperative Agreement number 58-0111-16-005.

Author Contributions: C.G. and B.M. jointly conceived the analysis, C.G., B.M. and M.P. wrote the paper.

Conflicts of Interest: The authors declare no conflict of interest.

\section{References}

1. Adams, R.M.; Rosenzweig, C.; Peart, R.; Ritchie, J.T.; McCarl, B.A.; Glyer, D.; Cury, R.B.; Jones, J.W.; Boote, K.J.; Allen, L.H. Global Climate Change and US Agriculture. Nature 1990, 345, 219-224. [CrossRef]

2. Sedjo, R.A.; Wisniewski, J.; Sample, A.V.; Kinsman, J.D. The economics of managing carbon via forestry: Assessment of existing studies. Environ. Resour. Econ. 1995, 6, 139-165. [CrossRef]

3. Jones, C.A.; Nickerson, C.J.; Heisey, P.W. New Uses of Old Tools? Greenhouse Gas Mitigation with Agriculture Sector Policies. Appl. Econ. Perspect. Policy 2013, 35, 398-434. [CrossRef]

4. McGlynn, E.; Galik, C.; Tepper, D.; Myers, J.; DeMeester, J. Building Carbon in America's Farms, Forests, and Grasslands: Foundations for a Policy Roadmap; Forest Trends and the Duke University Nicholas Institute for Environmental Policy Solutions: Washington, DC, USA; Durham, NC, USA, 2016.

5. McCarl, B.A.; Murray, B.C. Theme Overview: Revisiting the Evidence and Potential Solutions on Climate Change. Choices 2015, 30, 3.

6. Murray, B.C. Why Have Carbon Markets Not Delivered Agricultural Emission Reductions in the United States? Choices 2015, 30, 5.

7. U.S. Forest Service. Who Owns America's Forests? Forest Ownership Patterns and Family Forest Highlights from the National Woodland Owner Survey; U.S. Department of Agriculture, U.S. Forest Service, Northern Research Station: Amherst, MA, USA, 2008.

8. U.S. Environmental Protection Agency. Inventory of U.S. Greenhouse Gas Emissions and Sinks: 1990-2015; U.S. Environmental Protection Agency: Washington, DC, USA, 2017.

9. U.S. Forest Service. Future of America's Forests and Rangelands: Update to the Forest Service 2010 Resources Planning Act Assessment; U.S. Department of Agriculture, Forest Service, Washington Office: Washington, DC, USA, 2016.

10. Zhu, Z.; Reed, B.C. (Eds.) Baseline and Projected Future Carbon Storage and Greenhouse-Gas Fluxes in Ecosystems of the Eastern United States. Professional Paper 1804; U.S. Geological Survey: Washington, DC, USA, 2014. 
11. Zhu, Z.; Reed, B.C. (Eds.) Baseline and Projected Future Carbon Storage and Greenhouse-Gas Fluxes in Ecosystems of the Western United States. Professional Paper 1797; U.S. Geological Survey: Washington, DC, USA, 2012.

12. Bouchard, M.; Butman, D.; Hawbaker, T.; Li, Z.; Liu, J.; Liu, S.; McDonald, C.; Reker, R.; Sayler, K.; Sleeter, B.; et al. Baseline and Projected Future Carbon Storage and Greenhouse-Gas Fluxes in the Great Plains Region of the United States. Professional Paper 1787; Zhu, Z., Ed.; U.S. Geological Survey: Washington, DC, USA, 2011.

13. UNFCCC Revision of the "Guidelines for the Preparation of National Communications by Parties Included in Annex I to the Convention, Part II: UNFCCC Reporting Guidelines on National Communications". Available online: http://unfccc.int/resource/docs/2015/tp/03.pdf (accessed on 3 August 2017).

14. U.S. Department of State. Second Biennial Report of the United States of America: Under the United Nations Framework Convention on Climate Change; U.S. Department of State: Washington, DC, USA, 2016.

15. Murray, B.C.; Sohngen, B.L.; Sommer, A.J.; Depro, B.M.; Jones, K.M.; McCarl, B.A.; Gillig, D.; DeAngelo, B.; Andrasko, K. Greenhouse Gas Mitigation Potential in U.S. Forestry and Agriculture; Office of Atmospheric Programs, U.S. Environmental Protection Agency: Washington, DC, USA, 2005.

16. Adams, D.; Alig, R.; Latta, G.; White, E.M. Regional Impacts of a Program for Private Forest Carbon Offset Sales. J. For. 2011, 109, 444-453.

17. Baker, J.S.; McCarl, B.A.; Murray, B.C.; Rose, S.K.; Alig, R.; Adams, D.; Latta, G.; Beach, R.H.; Daigneault, A. Net Farm Income and Land Use under a U.S. Greenhouse Gas Cap and Trade. Policy Issues 2010, P17, 1-5.

18. Lubowski, R.N.; Plantinga, A.J.; Stavins, R.N. Land-use change and carbon sinks: Econometric estimation of the carbon sequestration supply function. J. Environ. Econ. Manag. 2006, 51, 135-152. [CrossRef]

19. The White House. United States Mid-Century Strategy for Deep Decarbonization; The White House: Washington, DC, USA, 2016.

20. U.S. Department of Agriculture. USDA Building Blocks for Climate Smart Agriculture and Forestry: Implementation Plan and Progress Report; United States Department of Agriculture: Erie, KS, USA; Quilcene, WA, USA, 2016.

21. Cherubini, F.; Bird, N.D.; Cowie, A.; Jungmeier, G.; Schlamadinger, B.; Woess-Gallasch, S. Energy- and greenhouse gas-based LCA of biofuel and bioenergy systems: Key issues, ranges and recommendations. Resour. Conserv. Recycl. 2009, 53, 434-447. [CrossRef]

22. Daigneault, A.; Sohngen, B.; Sedjo, R. Economic Approach to Assess the Forest Carbon Implications of Biomass Energy. Environ. Sci. Technol. 2012, 46, 5664-5671. [CrossRef] [PubMed]

23. Searchinger, T.; Heimlich, R.; Houghton, R.A.; Dong, F.; Elobeid, A.; Fabiosa, J.; Tokgoz, S.; Hayes, D.; $\mathrm{Yu}, \mathrm{T}$.-H. Use of U.S. Croplands for Biofuels Increases Greenhouse Gases through Emissions from Land-Use Change. Science 2008, 319, 1238-1240. [CrossRef] [PubMed]

24. Canter, C.E.; Qin, Z.; Cai, H.; Dunn, J.B.; Wang, M. Fossil energy consumption and greenhouse gas emissions, including soil carbon effects, of producing agriculture and forestry feedstocks. In 2016 Billion-Ton Report: Advancing Domestic Resources for a Thriving Bioeconomy; Oak Ridge National Laboratory: Oak Ridge, TN, USA, 2017; Volume 2, pp. 85-137.

25. U.S. Department of Agriculture; U.S. Environmental Protection Agency; U.S. Department of Energy. Biogas Opportunities Roadmap: Voluntary Actions to Reduce Methane Emissions and Increase Energy Independence. Available online: https:/ / www3.epa.gov/climatechange/Downloads/Biogas-Roadmap.pdf (accessed on 14 March 2017).

26. ICF International. Greenhouse Gas Mitigation Options and Costs for Agricultural Land and Animal Production within the United States; U.S. Department of Agriculture Climate Change Program Office: Washington, DC, USA, 2013.

27. Pape, D.; Lewandrowski, J.; Steele, R.; Man, D.; Riley-Gilbert, M.; Moffroid, K.; Kolansky, S. Managing Agricultural Land for Greenhouse Gas Mitigation within the United States; ICF International: Fairfax, WV, USA, 2016.

28. California Carbon CCA Forward Curve. Available online: http://californiacarbon.info/ (accessed on 24 May 2017).

29. Eagle, A.J.; Olander, L.P.; Henry, L.R.; Haugen-Kozyra, K.; Millar, N. Greenhouse Gas Mitigation Potential of Agricultural Land Management in the United States: A Synthesis of the Literature; Nicholas Institute for Environmental Policy Solutions, Duke University: Durham, NC, USA, 2012.

30. Depro, B.; Murray, B.C.; Alig, R.; Shanks, A. Public Land, Timber Harvests, and Climate Mitigation: Quantifying Carbon Sequestration Potential on U.S. Public Timberlands. For. Ecol. Manag. 2008, 255, 1122-1134. [CrossRef] 
31. National Conference of State Legislators State Renewable Portfolio Standards and Goals. Available online: http:/ / www.ncsl.org/research/energy/renewable-portfolio-standards.aspx (accessed on 26 April 2017).

32. Peters-Stanley, M.; Yon, D. Maneuvering the Mosaic: State of the Voluntary Carbon Markets 2013; Forest Trends' Ecosystem Marketplace and Bloomberg New Energy Finance: Washington, DC, USA; New York, NY, USA, 2013.

33. New Zealand Ministry for Primary Industries. Forestry in the Emissions Trading Scheme. Available online: https:/ / mpi.govt.nz/growing-and-producing/forestry/forestry-in-the-emissions-trading-scheme/ (accessed on 13 August 2017).

34. New Zealand Ministry for the Environment. New Zealand's Greenhouse Gas Inventory, 1990-2015: Snapshot. Available online: http://www.mfe.govt.nz/sites/default/files/media/Climate\%20Change/ Final\%20Snapshot_2\%20June\%202017.pdf (accessed on 13 August 2017).

35. New Zealand Ministry for the Environment. New Zealand's Emissions Trading Scheme. Available online: http:/ / www.mfe.govt.nz/climate-change/reducing-greenhouse-gas-emissions/new-zealand-emissionstrading-scheme (accessed on 13 August 2017).

36. Australian Government Department of the Environment and Energy. About the Carbon Farming Initiative. Available online: http:/ / www.environment.gov.au/climate-change/emissions-reduction-fund/cfi/about (accessed on 13 August 2017).

37. Murray, B.C.; Cropper, M.; de la Chesnaye, F.; Reilly, J.M. How Effective are U.S. Renewable Energy Subsidies in Cutting Greenhouse Gases? Am. Econ. Rev. Pap. Proc. 2014, 104, 569-574. [CrossRef]

38. Renewable Fuels Association. Tax Incentives. Available online: http://www.ethanolrfa.org/issues/tax/ (accessed on 15 June 2017).

39. Tomlinson, P.; Presley, D.; Rice, C. Greenhouse Gases in Agriculture; Kansas State University Research and Extension, Department of Agronomy: Manhattan, KS, USA, 2013.

40. Murray, B.C.; Galik, C.S.; Vegh, T. Biogas in the United States: Estimating Future Production and Learning from International Experiences. Mitig. Adapt. Strateg. Glob. Chang. 2017, 22, 485-501. [CrossRef]

41. Murray, B.C.; Vegh, T. Incentivizing the Reduction of Pollution at Dairies: How to Address Additionality When Multiple Environmental Credit Payments Are Combined; Nicholas Institute for Environmental Policy Solutions, Duke University: Durham, NC, USA, 2015.

42. The White House. Presidential Executive Order on Promoting Energy Independence and Economic Growth; The White House: Washington, DC, USA, 2017.

43. Butler, B.J.; Catanzaro, P.F.; Greene, J.L.; Hewes, J.H.; Kilgore, M.A.; Kittredge, D.B.; Ma, Z.; Tyrrell, M.L. Taxing Family Forest Owners: Implications of Federal and State Policies in the United States. J. For. 2012, 110, 371-380. [CrossRef]

44. Greene, J.L.; Straka, T.J.; Cushing, T.L. Effect of Taxes and Financial Incentives on Family-Owned Forest Land. The Southern Forest Futures Project: Technical Report. Gen. Tech. Rep. SRS-GTR-178; U.S. Department of Agriculture, U.S. Forest Service, Southern Research Station: Asheville, NC, USA, 2013.

45. Ronayne, K. California, New York, Washington Unite to Back Climate Pact; Associated Press: New York, NY, USA, 2017.

46. Ferris, J.; Newburn, D. Residential Development and the Effect of Forest Conservation Policy. In Proceedings of the Agricultural and Applied Economics Association Annual Meeting, Minneapolis, MN, USA, July 2014.

47. Thune, J. Thune Begins Farm Bill Rollout, Introduces New Income Protection Program for Farmers. Available online: https://www.thune.senate.gov/public/index.cfm/2017/3/thune-begins-farm-billrollout-introduces-new-income-protection-program-for-farmers (accessed on 1 June 2017).

48. Baker, J.S.; Galik, C.S. Policy Options for the Conservation Reserve Program in a Low-Carbon Economy; Climate Change Policy Partnership, Duke University: Durham, NC, USA, 2009.

49. Piñeiro, G.; Jobbágy, E.G.; Baker, J.S.; Murray, B.C.; Jackson, R.B. Set-asides can be better climate investment than corn ethanol. Ecol. Appl. 2009, 19, 277-282. [CrossRef] [PubMed]

50. Heller, M. Farmland Conservation Tops State Priority List for Rewrite; Environment \& Energy Publishing: Washington, DC, USA, 2017.

51. Thune, J. Background Information on Sen. John Thune's Phase II Farm Bill Rollout Conservation Title Improvements. Available online: https:/ / www.thune.senate.gov/public/_cache/files/eac6eab8-360f-415a863e-cd6b3ec8f9ed /FBCB0055BE99FF6649C15854721482C8.background-doc-farm-bill-final041017.pdf (accessed on 8 May 2017). 
52. Wear, D.N.; Coulston, J.W. From sink to source: Regional variation in U.S. forest carbon futures. Sci. Rep. 2015, 5. [CrossRef] [PubMed]

53. Fatka, J. What to Expect in the 2018 Farm Bill Debate. Available online: http://www.farmfutures.com/farmbill/what-expect-2018-farm-bill-debate (accessed on 21 March 2017).

54. Callaway, J.M.; McCarl, B.A. The Economic Consequences of Substituting Carbon Payments for Crop Subsidies in U.S. Agriculture. Environ. Resour. Econ. 1996, 7, 15-43. [CrossRef]

55. Miao, R.; Hennessy, D.A.; Feng, H. The Effects of Crop Insurance Subsidies and Sodsaver on Land Use Change. Working Paper 12-WP 530; Iowa State University, Center for Agricultural and Rural Development: Ames, IA, USA, 2012.

56. Upton, B.; Miner, R.; Spinney, M.; Heath, L.S. The Greenhouse Gas and Energy Impacts of Using Wood Instead of Alternatives in Residential Construction in the United States. Biomass Bioenergy 2008, 32, 1-10. [CrossRef]

57. Monke, J. Farm Bill Programs without a Budget Baseline Beyond FY2018; Congressional Research Service: Washington, DC, USA, 2017.

58. Khanna, M.; Chen, X.; Huang, H.; Onal, H. Land use and greenhouse gas mitigation effects of biofuel policies. Univ. Ill. Law Rev. 2011, 549-588.

59. Galik, C.S.; DeCarolis, J.F.; Fell, H. Evaluating the U.S. mid-century strategy for deep decarbonization amidst early century uncertainty. Clim. Policy 2017, in press. [CrossRef]

60. Lewandrowski, J.; Zook, K. GHG Mitigation in the Absence of a National Carbon Market. Choices 2015, 30, 6.

61. Walmart Walmart Launches Project Gigaton to Reduce Emissions in Company's Supply Chain. Available online: http://news.walmart.com/2017/04/19/walmart-launches-project-gigaton-to-reduceemissions-in-companys-supply-chain (accessed on 12 June 2017).

62. Langert, B. Smithfield Foods: Anatomy of a Sustainability Turnaround. Available online: https://www. greenbiz.com/article/smithfield-foods-anatomy-sustainability-turnaround (accessed on 26 May 2017).

63. Keystone Policy Center. Midwest Row Crop Collaborative: Scaling Solutions for Agriculture and the Environment. Available online: https:/ / www.keystone.org/wp-content/uploads/2016/08/MRCC-FAQ. pdf (accessed on 26 May 2017).

64. The Nature Conservancy NatureVest. Available online: http://www.naturevesttnc.org/ (accessed on 26 May 2017).

65. Harmon, M.E.; Ferrell, W.K.; Franklin, J.F. Effects on Carbon Storage of Conversion of Old-Growth Forests to Young Forests. Science 1990, 247, 699-702. [CrossRef] [PubMed]

66. Campbell, J.L.; Harmon, M.E.; Mitchell, S.R. Can Fuel-Reduction Treatments Really Increase Forest Carbon Storage in the Western US by Reducing Future Fire Emissions? Front. Ecol. Environ. 2012, 10, 83-90. [CrossRef]

67. Wear, D.N.; Murray, B.C. Federal timber restrictions, interregional spillovers, and the impact on US softwood markets. J. Environ. Econ. Manag. 2004, 47, 307-330. [CrossRef] 